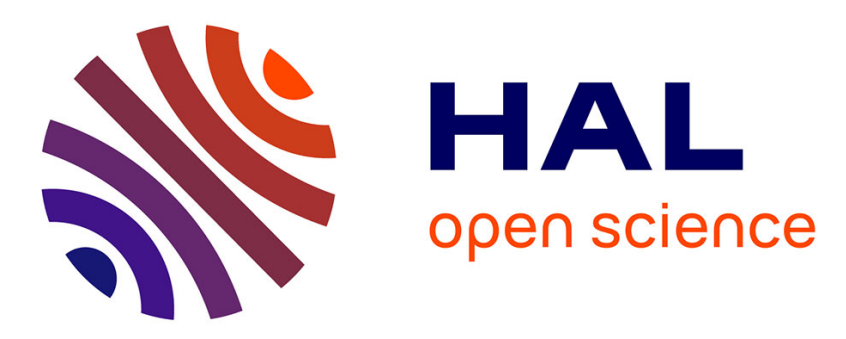

\title{
Assessing the effects of artificial light at night on biodiversity across latitude - Current knowledge gaps
}

Jean Secondi, Aurélie Davranche, Marc Théry, Nathalie Mondy, Thierry

Lengagne

\section{- To cite this version:}

Jean Secondi, Aurélie Davranche, Marc Théry, Nathalie Mondy, Thierry Lengagne. Assessing the effects of artificial light at night on biodiversity across latitude - Current knowledge gaps. Global Ecology and Biogeography, 2020, 29, pp.404-419. 10.1111/geb.13037 . hal-02379999

\section{HAL Id: hal-02379999 \\ https://univ-lyon1.hal.science/hal-02379999}

Submitted on 4 Jan 2021

HAL is a multi-disciplinary open access archive for the deposit and dissemination of scientific research documents, whether they are published or not. The documents may come from teaching and research institutions in France or abroad, or from public or private research centers.
L'archive ouverte pluridisciplinaire HAL, est destinée au dépôt et à la diffusion de documents scientifiques de niveau recherche, publiés ou non, émanant des établissements d'enseignement et de recherche français ou étrangers, des laboratoires publics ou privés. 
1 Assessing the effects of artificial light at night on biodiversity across

2 latitude - current knowledge gaps

3

4

5

6

7

8

9

10 Running title: Light pollution and biogeography 
Aim: Exposure to artificial light at night (ALAN) is a risk factor for organisms. Considering the spread and increasing intensity of night brightness across the globe, and the key role of light at all biological levels, alterations of ecosystems are expected. Yet, we cannot predict the severity of the effects of ALAN in several biomes because little information is available outside the temperate zone. We reviewed current knowledge and identified traits that could be targeted to fill this knowledge gap in order to contribute to the elaboration of a biogeographical framework for the study of ALAN at the global scale.

Location: global

Time period: current and next decades

Method: We analysed the latitudinal variation of ALAN and focused on environmental factors that vary with latitude but that have been overlooked. We reviewed biological traits that exhibit latitudinal variation and depend on light and photoperiod and compiled information about the predicted changes of human demography and road networks across different world regions.

Results: Cloud cover amplifies ALAN far away from urbanized areas. Because of the increased frequency of overcast night skies, exposure effects may be stronger both at high latitudes and across a large fraction of the intertropical zone, though at different times of the year. Intertropical biomes host the largest fraction of global biodiversity. Although currently they are not the most exposed to ALAN, their human populations are growing, and urbanized areas and road networks are expanding. Hence, ALAN could have strong ecological consequences, with cloud cover as an aggravating factor.

Perspectives: Knowledge gaps currently limit our ability to predict the effects of ALAN in different biomes. Therefore, it will be important to start investigating the consequences of this novel environmental factor across the globe, in order to develop a relevant theoretical framework

Keywords: ALAN, light pollution, intertropical, latitude, global change, biogeography, exposure 
Habitat loss, climate change, pollution, invasive species, and overexploitation negatively affect a large part of the Earth's ecosystems, if not all of them (Millenium Ecosystem Assessment, 2005). Artificial light at night (ALAN) is emerging as another potential threat to biodiversity worldwide (Bennie et al., 2015b; Davies \& Smyth, 2018). ALAN is mainly generated by urbanized areas and transport infrastructures, and exposure happens either via direct lights or via skyglow. The latter is produced by the scattering of light by atmospheric particles and aerosols from distant sources. It can be detected dozens of kilometres away from a major source like a city by animals (Kocifaj \& Lamphar, 2014; Aubé, 2015), whose sensitivity can be very high for nocturnal species (Kelber \& Roth, 2006; Kelber et al., 2017). ALAN now alters the natural photic regime across a large fraction of Earth (Cinzano et al., 2001; Longcore \& Rich, 2004). Recently, it has been estimated that $23 \%$ of land surfaces between $60^{\circ} \mathrm{S}$ and $75^{\circ} \mathrm{N}$ are exposed to light polluted skies (Falchi et al., 2016).

ALAN has been gaining attention from the scientific communities, authorities, and more generally societies. Concerns have initially sprung from astronomers that warned about the loss of quality of the nocturnal sky, and spread to other fields. New issues have been raised and expressed in reviews (Longcore \& Rich, 2004; Navara \& Nelson, 2007; Hölker et al., 2010; Gaston et al., 2013, 2015) and opinions (Nadis, 2002; Smith, 2009) for the last 15 years. ALAN generates a broad array of effects on animals, and as far as we know to a lesser extent on plants or micro-organisms (Hölker et al., 2015; ffrench-Constant et al., 2016; Bennie et al., 2017). These effects range from the molecular (Honnen et al., 2016) to the community (Rich \& Longcore, 2006a; Hölker et al., 2015; Bennie et al., 2017), and ecosystem level (Lewanzik \& Voigt, 2014; Sanders et al., 2015; Knop et al., 2017). As for the other major risk factors for biodiversity, ecosystem exposure to ALAN has been assessed at the global scale (Bennie et al., 2015b; Davies et al., 2016; Falchi et al., 2016; Kyba et al., 2017a; Guetté et $a l .$, 2018). The field is expanding fast as revealed by the recent bloom of publications (Davies \& Smyth, 2018). Nevertheless, no framework has been developed to predict whether and how the intensity of the effects caused by ALAN varies across the globe yet. 
environmental cue that resets circadian rhythms and prime seasonal change in activity (Coppack \& Pulido, 2004; Hut et al., 2013). Photoperiod varies widely with latitude and this affects the importance of light as a cue depending on the location on Earth. Similarly, a general biogeographic rule is the occurrence of latitudinal biodiversity clines, the intertropical zone hosting more species than temperate or arctic environments (Willig et al., 2003; Hillebrand, 2004; Mittelbach et al., 2007). Exceptions have been observed (Willig et al., 2003) but the statement holds true for vertebrates such as freshwater fishes (Abell et al., 2008), birds, mammals, amphibians (Jenkins et al., 2013), insects (Guenard et al., 2012), and vascular plants (Kreft \& Jetz, 2007). Surprisingly, while the major biodiversity hotspots are mainly located within the intertropical zone, we do not know whether the effects of ALAN in biodiversity are stronger at low than at mid or high latitudes.

From a literature survey on Scopus (accessed on 22/09/2019) using the combination of keywords (tropic* OR equat*) and "artificial light", "artificial” AND "light”, or "light pollution", we identified eleven references (Erkhert, 1976; Thakurdas et al., 2009; Lewanzik \& Voigt, 2014; Bennie et al., 2015b; Dorado-Correa et al., 2016; González-Bernal et al., 2016; Gupta \& Pushkala, 2016; De Freitas et al., 2017; Gineste et al., 2017; Rivas et al., 2018; Frank et al., 2019). Another search using the combination ("artificial light" OR "light pollution") AND "latitud*" accessed on Scopus on the same date yielded 59 hits. Four additional and partly relevant references were found. These were three reviews in which artificial lighting was not the main topic (Higuchi, 2010; Borniger \& Nelson, 2017; Brelsford et al., 2019), and one research paper on humans (Martín-Olalla, 2019). In comparison, a search using "light pollution" OR "artificial light", and restricted to the Agricultural and Biological Sciences section yielded 233 relevant references. More information is certainly present but not necessarily in papers addressing directly ALAN as previously noted (Rich \& Longcore, 2006b). Nevertheless, these figures highlight the publication bias between biomes and the fact that authors do not explicitly consider the biogeographical context.

Assessing the biological and ecological effects of ALAN at a global scale is now urgent. Yet, neither the systematic investigation of environmental factors varying at a biogeographic scale and 
affecting the sensitivity of organisms to ALAN, nor the identification of the areas/ecosystems/biomes the most threatened now or in the near future, has been undertaken. We need a biogeographic framework to assess how the exposure risk for biodiversity varies across ecosystems or regions, and we present here the first attempt in that direction. We will focus on the latitudinal variation of environmental factors that affect the photic regime, summarize what biological processes vary with latitude, and provide a prospective view of the evolution of ALAN with a particular emphasis on the intertropical zone.

\section{The geographical extent of ALAN and its effect on biodiversity}

ALAN exposure at a given site depends on the distance to the light sources, their power and spectral composition (Luginbuhl et al., 2014), the natural light regime (moon phase, visual barriers), and the atmosphere composition, including the presence and altitude of clouds. Cloud cover reflects artificial light downward and over large distances. For this reason, it has been identified as a major factor enhancing nocturnal light levels (Kyba et al., 2011; Kocifaj \& Lamphar, 2014). ALAN intensity, as measured by satellites, has kept increasing worldwide for the last decades, with local or regional variations (Falchi et al., 2016), and changes were still recently detected over a short 5-year period for most countries (Kyba et al., 2017a). All major ecosystems are now exposed (Bennie et al., 2015b), including the intertropical zone (Figure 1). To highlight this point, we used the data from the last published World Atlas (Falchi et al., 2016) and plotted the latitudinal distribution of ALAN in $5^{\circ}$ bins. The highest mean values were observed between $30^{\circ}$ and $40^{\circ}$ in both hemispheres. The standard deviation was maximal for northern temperate latitudes. However, the largest variation occurred around $10^{\circ} \mathrm{N}$ which is explained by the large expanses of darker land in Africa and brightly lit areas in northern Venezuela, Southern India, and Malaysia. ALAN keeps on increasing in this area. Between 2012 and 2016, an elevation of upward radiance in the intertropical zone was detected at the country level (Kyba et al., 2017a), while up to $35 \%$ of the area covered by tropical ecosystems in Brazil experienced higher brightness at night between 2008 and 2012 (De Freitas et al., 2017). 
Light intensities consistent with field measurements of ALAN alter the physiology of organisms, the behaviour of animals, and ecological processes. We will only outline the main traits and processes relevant to this article. For more extensive treatment, several review articles and book chapters have been published that can be referred to (Longcore \& Rich, 2004; Rich \& Longcore, 2006a; Perry et al., 2008; Gaston et al., 2013, 2015, 2017; Stevens \& Zhu, 2015; Grubisic et al., 2018; Owens \& Lewis, 2018; Desouhant et al., 2019). ALAN affects activity and time partitioning (Rich \& Longcore, 2006a; Le Tallec et al., 2013; Dominoni et al., 2014; Da Silva et al., 2015), orientation (Salmon, 2003; Pawson \& Bader, 2014; Thums et al., 2016), space use (Moore et al., 2000; Stone et al., 2009), foraging (Dwyer et al., 2013; Cravens et al., 2017; van Langevelde et al., 2017), social interactions including sexual behaviour (Kurvers \& Hölker, 2015; van Geffen et al., 2015; Firebaugh \& Haynes, 2016), and lifehistory traits (Van Geffen et al., 2014). Foraging behaviour can be modified in opposite ways depending on the focal species (Dwyer et al., 2013; Cravens et al., 2017). At the sensory level, the effects of ALAN primarily depend on the spectrum and intensity of ambient light, and the photoreceptor characteristics (Endler, 1990). Individuals, in insects or amphibians for instance, can be attracted or repelled by unusual brightly lit areas (Hailman \& Jaeger, 1974; Owens \& Lewis, 2018), but more subtle process can be altered, like colour vision. Dim-light colour vision based on cones in insects and reptiles (Kelber \& Roth, 2006), and rods in amphibians (Gomez et al., 2009; Yovanovich et al., 2017) has now been demonstrated. Therefore, the capacity of individuals to detect and select food items, or catch prey can be modified under ALAN because the contrast between the target and the background is altered. metabolism, sleep and cognitive disorders, depression syndrome, and may increase risk of some cancers

140 (Stevens et al., 2013; Borniger et al., 2014; Bedrosian et al., 2015; Chellappa et al., 2018). It inhibits 141 the production of melatonin, a hormone that modifies stress response, mitochondria functioning, 
oxidative stress, metabolism, and immune defence (Carrillo-Vico et al., 2005; Tan et al., 2010; Tallec et al., 2016). Melatonin holds a central role in these processes because of its multifarious effects on circadian timekeeping and the regulation of biological rhythms (Hardeland et al., 2011). The circadian variation of melatonin has been observed from bacteria to vertebrates (Tan et al., 2010), and the effects of this molecule on clock genes have been demonstrated in vertebrates and arthropods. These molecular mechanisms likely date back at least to the cnidarian-bilaterian divergence (Peres et al., 2014), which illustrates the taxonomic breadth of groups potentially affected by ALAN. The strength of the effects may depend on the diel activity patterns, with cathemeral species being probably less sensitive to changes in photoperiod than diurnal, nocturnal or crepuscular species. In plants, effects on physiological processes, including photosynthesis, and photoperiodism are expected (Aubé et al., 2013; Singhal et al., 2019). Individuals need to be relatively close to the light sources but physiological effects have been observed (Bennie et al., 2016, 2017; ffrench-Constant et al., 2016). The uncoupling between the thermal and photic cues caused by ALAN may affect the timing of seasonal processes like dormancy (Aubé et al., 2013; Hut et al., 2013; ffrench-Constant et al., 2016; Solano-Lamphar \& Kocifaj, 2018). However, the actual consequences for plant population largely remain to be investigated (Knop et al., 2017; Macgregor et al., 2019).

Because of the biological effects cited above, ALAN is expected to affect ecological processes like energy or nutrient fluxes or relationships in trophic networks (Longcore \& Rich, 2004; Perkin et al., 2011; Gaston et al., 2013; Meyer \& Sullivan, 2013; Bennie et al., 2015a; Mathews et al., 2015; Sanders et al., 2015; Knop et al., 2017; MacGregor et al., 2017; Miller et al., 2017). More generally, the synchronisation between the components of any interspecific interactions can be altered (Bennie et al., 2015a; Helm et al., 2017; Kronfeld-Schor et al., 2017). Therefore, behavioural and physiological effects on individuals may scale up to the population, community and ecosystem level (Sanders \& Gaston, 2018). Evidence of disruption on micro-organism, arthropod, and plant community has been provided (Meyer \& Sullivan, 2013; Pawson \& Bader, 2014; Hölker et al., 2015; Bennie et al., 2017; Knop et al., 2017), but so far no evidence of large scale effects on ecosystems have been reported. Nevertheless, studies showing reduced efficiency of plant pollination by insects (Knop et al., 2017; 
MacGregor et al., 2017) and bats (Lewanzik \& Voigt, 2014), or increased predation on agricultural pest by insect (Miller et al., 2017) suggest that large effects may occur in natural environments and agrosystems.

\section{Natural factors modulating exposure to ALAN at the global scale}

To understand how ALAN affects organisms and populations depending on their position on the globe, the geographical variation of factors that naturally determine the light-dark regime should be considered: photoperiod, lunar cycle, twilight, and climate. Photoperiod varies in a predictable way, with annual variation in daylength increasing with latitude, from about $0 \%$ at the Equator to $100 \%$ at the Arctic Circle.. In other words, photoperiod is more constant towards the Equator and more variable towards the poles.

Moonlight is the brightest nocturnal light source in pristine environments. The lunar cycle lasts 29.52 days and is synchronous at all latitudes. While Moon phase and Earth-Moon distance change, the former parameter contributes much more to the variation of illuminance. Natural maximal illuminance on Earth and under optimal conditions is 0.32 lux and in the intertropical zone only. Because of its orbital plane, the Moon can be seen at the sky zenith, where illuminance is maximal, only at locations lower than $28^{\circ}$ latitude (Kyba et al., 2017b). Thus, the Moon is less bright at higher latitudes. Illuminance lies typically within 0.05-0.2 lux at mid-latitude (Kyba et al., 2017b). Brightness varies with season because of the change in the distance to the Sun and elevation. Moon elevation is higher in winter than in summer.

The variation in duration and intensity of moonlight cannot be used to determine the exact time or date. Yet, moonlight is more and more recognised as a major feature on the nocturnal environment for animals. Effects on activity, orientation, and communication have been observed in invertebrates and vertebrates (Dacke et al., 2003; Grant et al., 2009; Kronfeld-Schor et al., 2013). In particular, moonlight is expected to suppress activity to reduce predation risk, especially in open habitat species. 
This prediction was confirmed in amphibians (Vignoli \& Luiselli, 2013) and all groups of nocturnal mammals but primates for which higher activity during bright nights may reflect a better ability to detect predators and forage (Prugh \& Golden, 2014). One direct consequence of ALAN is that elevated brightness tends to mask the natural photic variation as moonlight is attenuated against the skyglow background (Davies et al., 2013a).

Twilight is the transition between day and night when Sun drops under the horizon. It is split into three periods that are characterized by the Sun declination and the colour of ambient light. During the civil twilight the sun declination lies between 0 and $6^{\circ}$. Light level drops sharply during the nautical twilight (declination 6-12 ${ }^{\circ}$ ) and less quickly during the astronomical twilight (declination $12-18^{\circ}$ ). Irradiance turns from a red dominant spectrum to a blue dominant spectrum (Johnsen, 2011). After twilight, the irradiance spectrum of the sky depends on the Moon and other light sources. There is a latitudinal cline in twilight duration that is shorter at lower latitudes (Figure 2). Some authors have considered as "semi-darkness" the merged periods of twilight and lunar phases where at least $26 \%$ of the Moon is visible (Mills, 2008). Darkness is a relatively vague concept given the variable visual capacity of species under dim light (Kelber \& Roth, 2006). Nevertheless, the duration of natural semidarkness remains constant around $4.5 \mathrm{~h}$ at the Equator and varies widely from $0 \mathrm{~h}$ to $9 \mathrm{~h}$ at $75^{\circ}$ (Mills, 2008) and forms a gradient parallel to the photoperiod gradient. ALAN generates light levels in the same range of those observed during natural twilight and can, therefore, extend the duration of this period. Circadian rhythms which are reset with twilight. The rapid changes in light intensity and colour are reliable cues to determine the onsets and the ends of activities like foraging or mating (Daan \& Aschoff, 1975; Andersson et al., 1998; Boulos \& Macchi, 2005).

The importance of cloud cover in the global assessment of ALAN has probably been overlooked. Clouds amplify light emitted from the ground, extend the photophase in light-polluted areas whereas they mask celestial objects, dim their lights, and shorten the photophase in non-polluted areas. It is important to keep in mind that global models of ALAN underestimate exposure at ground level because they use upward radiance recorded from satellite images. The representation of a cloud-free world elicited by these images may thus bias our perception of the phenomenon. The spatial extent of ALAN 
during overcast nights is much broader (Kyba et al., 2011; Kocifaj \& Lamphar, 2014). A logical

conclusion is that, all other factors being equal, the intensity, spread, and the annual number of days with high levels of ALAN should be related to the annual number of days with overcast skies, although rain or mist could strongly attenuate light transmission. Because cloud cover is crucial to determine the spatial extent of ALAN, it is important to consider how uneven its annual distribution on Earth is. A recent multi-year study of cloud cover mapped the average cloud fraction (number of pixels covered) across the World during the day and at night. Figure 1 shows the latitudinal distribution of cloud fraction between July 2002 and April 2018 excluding seas and large lakes. Higher values were observed in the Arctic and subarctic regions and within the intertropical zone where cloud cover was particularly high in Central Africa, the Amazonian basin and Central America, India, and south-east Asia (King et al., 2013). The annual variation in cloud cover is also the lowest for both areas. Owing to latitude and cloud cover, organisms in the intertropical zone often experience a stable photoperiod and on average a darker visual environment than in any other region on the globe. In the tropics, the variation in cloud cover is maximal and cloud cover low due to the presence of areas with arid or humid climates. Changes in the fraction of high clouds, and precipitation have been observed in the intertropical convergence zone but the expected trends for the next decades are still debated (Legates et al., 2014; Mauritsen \& Stevens, 2015; Norris et al., 2016; Wodzicki \& Rapp, 2016). Rainfall is also expected to decrease or increase depending on regional trends (Kitoh et al., 2013; IPCC, 2014), and uncertainty is higher for rainfall than temperature models especially in the tropics (Corlett, 2012). Furthermore, a consensual prediction is a higher frequency of extreme rainfall events, largely in the form of storms shorter than a day (Westra et $a l ., 2014)$, which may not affect the annual number of overcast days. More robustness in climate models related to cloud cover and precipitation is needed to more precisely assess the exposure of ecosystems to ALAN across the Earth. 


\section{Biological traits vary with latitude}

Because of its influence on annual daylength variation, climate, and its current correlation with economic development, latitude is a key factor that is expected to modulate the sensitivity of populations to ALAN. We illustrate how the latitudinal variation in photoperiod influences variation in circadian rhythms, photoperiodism for major life-history traits like reproduction or migration (Hut \& Beersma, 2011; Van Geffen et al., 2014; Gaston et al., 2017; Helm et al., 2017), or the characteristics of sensory systems (Yammouni et al., 2011). Annual life-history events are often synchronised with photoperiod so that organisms anticipate changes in forthcoming environmental conditions. Latitudinal variation in photoperiod determines changes in the timing of major events like migration, reproduction in birds, or diapause in insects. In birds, photoperiod is a major cue for the onset of gonadal maturation, moult, and migratory activity (Rowan, 1925; Gwinner, 1996; Dawson et al., 2001; Coppack \& Pulido, 2004; Bauer et al., 2008). Great tits Parus major need longer days to initiate sexual maturation at mid-latitude than at higher latitudes, causing a cline in the onset of male gonadal maturation (Silverin et al., 1993). The required daylength variation can be as small as $1 \mathrm{~h}$ or less to initiate sexual maturation in temperate (Dawson, 2007) and subtropical species (Lewis et al., 1974; Hau et al., 1998; Coppack \& Pulido, 2004). Photoperiod also largely contributes to induce diapause and to regulate voltinism in insects. Critical photoperiod for diapauses increases with latitude (Danilevskii, 1965; Bradshaw \& Lounibos, 1977; Hut et al., 2013) and the number of diapausing individuals with shorter daylength (Schmidt et al., 2005; Hut et al., 2013; Paolucci et al., 2013). Photoperiod and local environmental conditions determine the number of generations per year, more generations being produced at lower latitudes (Altermatt, 2010). For instance, in the water strider Aquarius remigi, univoltinism is less frequent in southern populations, and change in growth occurred across a narrow range of $5^{\circ}$ (Blanckenhorn \& Fairbairn, 1995). In mammals, latitudinal variation in the timing of the breeding period was observed in the broadly distributed Peromyscus deermice and Odocoileus deers, and photoresponsiveness decreased with latitude in a mouse (Bronson, 1988).

Circadian clocks are found from cyanobacteria to plants and animals (Hut \& Beersma, 2011). They generate endogenous circadian rhythms that synchronize physiological processes and activities of 
organisms to the diel variation of environmental conditions. Light is the main cue used to reset circadian clocks, which explains why activity patterns and other behaviours change with latitude. In mammals, the occurrence of nocturnal and diurnal species is higher in the intertropical zone whereas crepuscular and cathemeral species are distributed at higher latitudes, thus reflecting the adaptation to larger variation in annual daylength and longer twilight periods (Bennie et al., 2014). The photic regime of Arctic regions favours behavioural plasticity. For instance, populations of Reindeer Rangifer tarandus above $70^{\circ} \mathrm{N}$ lose their circadian rhythm of activity in summer and recover it in autumn and spring (Van Oort et al., 2005), while the Arctic sandpiper Calidris melanotos undergo a drastic reduction of sleep during the mating period as a likely result of prolonged sexual activity under long days conditions (Lesku et al., 2012). A large comparative study on shorebirds detected a latitudinal cline in incubation behaviour (Bulla et al., 2016). The influence of photoperiod was lower at higher latitudes. Although the dataset is impressive, the study included temperate, boreal and arctic populations between $35^{\circ}$ and $75^{\circ}$, and none from the intertropical zone. Latitudinal variation in diel activity patterns is observed at the intraspecific level too. In Drosophila melanogaster, ovoposition peaks at dusk at the beginning of the dark period. In a rare study ranging from $0^{\circ}$ to $60^{\circ} \mathrm{N}$, authors showed that the percentage of eggs laid during the dark period decreases from $80 \%$ in Equatorial populations to less than $50 \%$ in Northern Scandinavia (Allemand \& David, 1976). Similarly, an earlier study showed that the onset and end of locomotor activity of five bird and three mammal species held in captivity at $47^{\circ} \mathrm{N}$ and $66^{\circ} \mathrm{N}$ varied more between days at higher latitude (Daan \& Aschoff, 1975). Variation was reduced when species activity occurred during the civil twilight when light spectrum changes rapidly. Another study ranging from $37^{\circ} \mathrm{N}$ to $65^{\circ} \mathrm{N}$ across Europe found that the onset of dawn singing depended on latitude in some passerines. Under ALAN conditions, it was advanced for latitude-insensitive species only (Da Silva \& Kempenaers, 2017).

Sensory systems experience circadian and seasonal regulation. In vertebrates, the expression of photoreceptors, and the detection of colour stimuli follow rhythms that are synchronized by photoperiod

298 (Terman \& Terman, 1985; Cahill \& Beshare, 1995). In fishes (Shimmura et al., 2017) and humans 299 (Welbourne et al., 2015) seasonal changes in colour perception occur. The visual system also varies 300 with latitude. In fishes retinomotor movements are observed during which rods and cones move in 
opposite ways across the retina depending on the time of the day (Yammouni et al., 2011). Retinomotor movements during twilight track the changes in illumination and keep vision functional. They follow endogenous rhythms as demonstrated in individuals kept in the dark or exposed to light during the dark period. Fishes may rely more on changes in ambient illumination and less on endogenous oscillators at higher than at lower latitudes (Yammouni et al., 2011).

\section{A predictive biogeographical framework for ALAN is lacking}

Beyond the characteristics of the light sources, exposure to ALAN depends on the time of the year, latitude, and climate. Logically, individuals should be less exposed during long-day periods than during short-day periods. Figure 2 illustrates for three towns at low $\left(6^{\circ} \mathrm{N}\right)$, medium $\left(43^{\circ} \mathrm{N}\right)$, and high $\left(64^{\circ} \mathrm{N}\right)$ latitude the monthly variation in sunrise and sunset, as well as the time of the astronomical sunrises and sunsets. Before astronomical sunrise and after astronomical sunset, the sun does not contribute to the ambient light level, and it is a conservative approach to determine when sky brightness will be for sure elevated beyond its natural value by ALAN, at least during moonless nights or under overcast skies. We represented the number of extra-lit hours due to ALAN before and after the astronomical twilight for two lighting scenarios. Lights are turned off at midnight in the first scenario, as an energy-saving measure, and remain turned on all night in the second. The pattern is the same for the two scenarios, but the number of extra-lit hours due to ALAN is larger for the second. At high latitude, there are no extra-lit hours for about 5 months, which period is used for breeding in many arctic species. One can predict the disruption to be mild or non-existent then. In contrast, ALAN duration is maximal during wintertime. Effects could be positive if artificial light allows longer foraging periods or negative if it raises activity and metabolic cost beyond sustainable levels for organisms. At low latitude, the extent of artificial lighting is constant throughout the year. Therefore, disruption may affect any lifehistory events regardless of annual timing. At mid-latitudes, the number of extra-lit hours is minimal around summer equinox, which often corresponds to the end of breeding for birds or amphibians, but is the main active period for insects or bats. The extension of ALAN is maximal in winter and the concern is the same as for arctic organisms with the addition that reproduction occurs in winter for some 
mammals too. In temperate species, the seasonal effect of ALAN may be more diverse than at lower or higher latitudes and depend on the taxonomic group.

We have knowledge about the latitudinal variation of some traits and expectations about how exposure to ALAN may change across latitudes and seasons. Yet, we still do not know whether and how latitude determines the short or long-term responses of individuals and populations to ALAN. We make some propositions to go forward in that direction by pointing to candidate traits that would deserve more attention. We also make some predictions about the evolutionary responses that could be expected at different latitudes. Most physiological or behavioural traits are potentially affected but we can nevertheless identify some traits to address key issues, namely whether and how the strength of ALANinduced effects varies with latitudes, if some periods of the year are more critical for biodiversity exposed to ALAN, and whether these periods change latitudinally. A major pending question is whether latitude can predict at least qualitatively the time taken by populations to develop responses to ALAN exposure.

As mentioned above, a longer photoperiod could have beneficial or detrimental effects on individuals in terms of time and energy budget. Thus, it is important to determine whether diurnal and nocturnal species respectively prolong or delay their activity period, and how they partition key activities like foraging or reproduction during a day. In this regard, light pollution may contribute to the stronger homogenizing effect of urbanization on nocturnal moths than on diurnal butterflies (Merckx \& Van Dyck, 2019). The latitudinal effect on incubating bouts in shorebirds (Bulla et al., 2016), where ALAN exposure was not assessed, or on the advanced onset of dawn singing in passerines (Da Silva \& Kempenaers, 2017), illustrate which type of behaviour could be targeted. Focusing on activity alone may not unravel the complexity of the disruption process for organisms. The diel distribution of feeding bouts was altered in mice, resulting in obese individuals (Fonken et al., 2010), while activity and metabolism were uncoupled in amphibians exposed to light at night (Touzot et al., 2019). These lab studies highlight the need for analysing together activity and metabolic budgets or relevant proxies when other physiological measurements cannot be made. Because physiological constraints may be stronger at higher than at lower latitudes, short-term effects on survival may be quicker. More generally, we do 
not know well how circadian clocks are affected by ALAN in most species. Even less do we know about how the clocks of populations located at different latitudes respond to novel photic regimes. Birds provide a good illustration of our limited capacity to predict the effects of ALAN in animals. Life-history traits like the onset of breeding, migration, dispersal, moult are important for individual fitness and population growth rate. They are all potentially affected by ALAN even in populations at low latitudes. The increase in the apparent daylength by ALAN may lead to maladaptive decision by desynchronizing the onset of biological events and the time window of optimal climate/trophic conditions. Desynchronization may affect the reproductive output and survival of individuals in resident intertropical species and migratory species. For instance, the extension of the photoperiod by ALAN could affect photorefractoriness, i.e. the loss of sensitivity to long days that prevents the initiation of spring migration and maturation. Slight changes in migration timing in a context of climate change may have negative consequences for bird populations. We simply do not know whether the sensitivity to the disturbance generated by ALAN depends on latitude and hardly what to predict. At the sensory level, ALAN is expected to affect the efficiency of visual tasks carried out at night or under crepuscular conditions like orientation (Somanathan et al., 2008), or the selection of food sources (Kelber et al., 2002), or mates (Gomez et al., 2009). Adaptation to the light/dark transitions may be partly inefficient in populations that do not use photic cues to reset the circadian rhythm of their visual system (Yammouni et al., 2011).

The novel pattern of annual daylength variation generated by ALAN may not be necessarily harder to overcome, at the evolutionary scale, than the colonization of higher latitudes for a species though. Latitudinal clines in activity illustrate the evolutionary potential of some populations to adjust to spatially heterogeneous conditions even over a few degrees of latitude (Blanckenhorn \& Fairbairn, 1995). In the long-term, populations are expected to develop higher resistance to this novel disturbance (Hopkins et al., 2018). For instance, urban populations of a moth developed a lower attraction to light than populations from less non-polluted areas (Altermatt 2018). A major issue is which response type should be favoured at different latitudes and what time scale is relevant for such changes to occur. The stability of the natural daylength and the ALAN period should favour adaptation to a longer photophase 
at lower latitudes unless the physiological and ecological costs of plasticity are small (DeWitt et al., 1998). In contrast, plastic phenotypes able to respond to varying daylength should be selected at higher latitudes. In this regard, it has been argued that individuals rely more on transitions between the light and dark period than on internal oscillators at higher latitudes, whereas the opposite pattern should be observed at lower latitudes (Gaston et al., 2017; Helm et al., 2017). Whether plasticity is adaptive in winter time, when the higher numbers of extra-lit hours may require a higher energetic demand, remains to be tested. We observed a limit to the studies on the latitudinal variation of biological traits. The behavioural and physiological clines observed at the interspecific or intraspecific level spanned a fraction of the latitudinal range between temperate and higher latitudes. Information about the transition between the intertropical and the temperate zones is lacking. However, such knowledge is necessary if we want to build a biogeographical framework robust enough to predict the latitudinal effect of ALAN. This publication bias has been noticed for the study of the evolution of breeding in mammals (Bronson, 1988). It is likely that the historical distribution of laboratories and the difficulty to identify species or groups of species spanning the entire latitudinal range, as well as the logistic constraint of these studies, account for the current situation. Up to now, only a few species distributed across the whole range like D. melanogaster have been tested (but see Bronson (1988) for mammals).

\section{Prospective view about the geographical spread of ALAN: a concern for} intertropical biomes?

The increase of ALAN essentially results from demographic growth and economic development, i.e. the greater use of electricity. World population is forecast to grow from 7.5 billion in 2017 to 9.8 billion in 2050 and over 11 billion in 2100 (United Nations Department of Economic and social affair Population division, 2017). Between 2017 and 2050, the intertropical region including Western, Middle and Eastern Africa should increase its population by $217 \%$. South-Eastern Asia, and the region including Central 
and $21 \%$. In comparison population in Europe and Eastern Asia should decrease by $4 \%$ and Northern America raise by $20 \%$ (United Nations Department of Economic and social affair Population division, 2017). Larger use of lighting can also be predicted according to prospective studies that forecast the expansion of urban areas and road networks. Roads generate light by their traffic, but they also facilitate new settlements and the expansion of existing settlements. A recent study predicted an increase of 185 $\%$ of the global urban extent between 2000 and 2030 for the land category with the highest probability of being urbanized (Seto et al., 2012). In Africa a $590 \%$ increase of urbanized areas is expected with a concentration of this process in five areas, four of which are located in the intertropical zone. Furthermore, the percentage of urbanization in 34 World major biodiversity hotspots is predicted to triple during that period. The largest changes are expected in regions undisturbed by urban development so far, and all concern inter-tropical areas (Seto et al., 2012). Regarding road networks only $43 \%$ of the emerged land (except Antarctica and Greenland), were considered roadless, i.e. distant more than $5 \mathrm{~km}$ from a road, in 2016 (Ibisch et al., 2016), a distance at which a nocturnal light source is detected. In tropical and subtropical countries, one-fifth of national parks is crossed by at least one main road (Caro et al., 2014). Expansion of logging creates roads and gaps that are likely to increase exposure to light in the vicinity of human settlements (Laporte et al., 2007). Therefore, population growth, urbanized land, and road networks are expected to keep growing in the next decades especially in areas of high conservation value and in the intertropical zone (Figure 3).

International initiatives seeking to increase the access to electricity in developing countries are welcome (see for instance www.AREI.org), but they may contribute to the increase of night brightness in preserved environments. There is little doubt that a larger fraction of land in the intertropical zone will experience higher levels of ALAN in the next decades. The increasing use of LEDs for outdoor lighting may further deteriorate the nocturnal environment and generate more deleterious effects for biodiversity than older technical solutions (Cajochen et al., 2011; Davies et al., 2013b; Pawson \& Bader, 2014). For a given power, LEDs provide better lighting conditions than older sodium lamps because they stimulate a broader range of the visual system of many organisms (Davies et al., 2013b). In addition, this cheaper technology tends to favour greater use of nocturnal light (Kyba et al., 2017a). Countries in 
the intertropical zone are developing their territory and will likely use the technology that is the most disrupting for biodiversity. By doing so, they will generate a more sudden change than the one experienced by wildlife earlier in other parts of the World. Such a rapid transition in lighting has been documented in Peru (Kyba et al., 2017a). At a broader scale, an increase in nocturnal light was detected by satellites in the tropical/subtropical biomes. The proportion of the area that experienced higher brightness raised by $2 \%$ between 1992-1996 and 2008-2012. The largest increase was observed for needle-leaf and mixed forests that occupy a restricted fraction of the total area but host rich endemic biodiversity (Bennie et al., 2015b).

\section{Conclusion}

We are clearly lacking a biogeographical framework to predict how species adapt or acclimate to ALAN and by which way. We do not know in which biomes ecological networks are the most sensitive to the elevation of nocturnal brightness, which ecosystems will be the most strongly exposed in the near future, and to which extent climate modulates exposure to ALAN at a given latitude. Only fragmentary information is available to generate testable hypotheses. Climate has probably a still unappreciated influence on the intensity of the biological and ecological effects of ALAN. In particular, more attention should be paid to the geographical variation in cloud cover. A higher sensitivity to change in nocturnal ambient light is expected in organisms from ecosystems where cloud cover is frequent because nocturnal light intensity is often low. Furthermore, within the same latitudinal range, areas where rain, fog, or mist is frequent may be less exposed than arid areas where moonlight is more present most of the nights, and negative effects on organisms and ecosystems may be milder. In forest, light exposure depends on the position of the organism relative to canopy. A large fraction of tropical forest biodiversity lies at the canopy level where individuals are more easily exposed to distant sources of ALAN. Under the canopy where the light level is very low, species are probably less exposed, but they could be highly sensitive 
to small changes in light intensity. Species naturally living in forest edges, clearings, riparian or open habitats may be more exposed and suffer more from new lighting conditions. In this regard, roads or clearings in tropical forest generate a barrier effect, many organisms avoiding gaps as narrow as 30 meters (Laurance et al., 2009). The occurrence of ALAN in an otherwise dark environment could strongly enhance the barrier effect for these species (Lewanzik \& Voigt, 2014). is a necessary step but it may not be sufficient. The spread of light at night co-occurs with the other drivers of biodiversity decline such as habitat fragmentation, chemical pollution, invasive species, that all generate stress for individuals. Negative synergistic effects of multiple stressors on organisms and populations are well known (Sih et al., 2004). Climate change is likely the main global factor to focus on. A recent review highlighted the negative effects on animal fitness of changing climate under stable photoperiod (Walker et al., 2019). The evolution towards a less frequent or less reflecting cloud cover would reduce exposure of organisms in terms of intensity and duration but also the size of the areas experiencing light pollution, compensating in a way the expansion of urbanized area. In contrast, more clouds are likely to enhance the biological and ecological effects of ALAN. Temperature, the main focus of attention of climate change, is also relevant. It modulates biological rhythms entrained by light (Underwood, 1989; Helm et al., 2017), resets circadian clocks (Chen et al., 2015), affects gene expression in insects and mammals (Helm et al., 2017), alters the daily expression peak of melatonin in lower vertebrates (Mayer et al., 1997), and induces seasonal shift from nocturnality to diurnality in insects and mammals (van der Vinne et al., 2014; Helm et al., 2017). The sensitivity of insects to warming is believed to be the highest in the intertropical zone because individuals are already close to their thermal tolerance threshold (Deutsch et al., 2008). The annual covariation of temperature and 480 photoperiod at a location determines an environmental envelope that enlarges in both dimensions with 481 latitude (Hut et al., 2013), as a result of increasing temperature and daylength range. Global warming 482 changes one dimension of the envelope while ALAN changes the other dimension, giving rise to entirely new conditions with unknown consequences about the desynchronization of physiological and behavioural rhythms at the individual level, and the timing and intensity of interspecific relationships at 
the ecological level (but see Miller (2017)). Effects are expected at any location on the globe but predicting the outcome of the interaction remains difficult since temperature is rising faster at higher latitudes (Hansen et al., 2006) and light at night strongly changes the photic regime year-round at lower latitudes.

The demographic and macro-economic projections for the next decades support the expansion of ALAN across the World and particularly within the intertropical zone. Because synergies with other drivers of global decline are not known so far, even if some may be anticipated, prevention and caution remain the most appropriate approaches. We did not attempt a meta-analysis of the papers published on biological rhythms or ALAN for species in the intertropical zone but it is no doubt that there are many less than papers devoted to temperate or high-latitude species. The time is ripe to shift the balance and start investigating the effects of ALAN at different latitudes. In particular, attention should be given to the capacity of intertropical species to respond to the novel conditions generated by ALAN and climate change. A good starting point could be to focus on groups originating from the intertropical zone. Habitat loss, climate change, overexploitation have received so far the main attention in many areas for obvious reasons. It should be acknowledged that ALAN might be a more insidious form of threat to local biodiversity. Eco-tourism has been a major source of income for several countries and it is becoming a major contribution for new ones particularly in countries benefiting from hotspots. It may also contribute to accelerate the change of the photic environment at night. In this regard, a recent global study showed that the increase in ALAN was much higher around protected areas than farther away (Guetté et al., 2018). The demand for biodiversity will keep on growing with the global human population. A cautionary message would be to remind that increasing population, infrastructures and facilities, and more generally the use of electricity for nocturnal lighting may be harmful even in the most environment-friendly areas that value biodiversity as a resource for their economic development. 


\section{References}

512

Abell, R., Thieme, M.L., Revenga, C., Bryer, M., Kottelat, M., Bogutskaya, N., Coad, B., Mandrak, N., Balderas, S.C., Bussing, W., Stiassny, M.L.J., Skelton, P., Allen, G.R., Unmack, P., Naseka, A., Ng, R., Sindorf, N., Robertson, J., Armijo, E., Higgins, J. V., Heibel, T.J., Wikramanayake, E., Olson, D., López, H.L., Reis, R.E., Lundberg, J.G., Sabaj Pérez, M.H. \& Petry, P. (2008) Freshwater Ecoregions of the World: A New Map of Biogeographic Units for Freshwater Biodiversity Conservation. BioScience, 58, 403.

Allemand, R. \& David, J.R. (1976) The circadian rhythm of oviposition in Drosophila melanogaster: A genetic latitudinal cline in wild populations. Experientia, 32, 1403-1405.

Altermatt, F. (2010) Climatic warming increases voltinism in European butterflies and moths. Proceedings of the Royal Society B: Biological Sciences, 277, 1281-1287.

Andersson, S., Rydell, J. \& Svensson, M.G.E. (1998) Light, predation and the lekking behaviour of the ghost swift Hepialus humuli (L.) (Lepidoptera, Hepialidae). Proceedings of the Royal Society B: Biological Sciences, 265, 1345-1351.

Aubé, M. (2015) Physical behaviour of anthropogenic light propagation into the nocturnal environment. Philosophical Transactions Royal Society B, 370, 20140117.

Aubé, M., Roby, J. \& Kocifaj, M. (2013) Evaluating potential spectral impacts of various artificial lights on melatonin suppression, photosynthesis, and star visibility. PLOS ONE, 8, 1-15.

Bauer, S., Gienapp, P. \& Madsen, J. (2008) The relevance of environmental conditions for departure decision changes en route in migrating geese. Ecology, 89, 1953-1960.

Bedrosian, T.A., Fonken, L.K. \& Nelson, R.J. (2015) Endocrine effects of circadian disruption. Annual Review of Physiology, 78, 150724172241001.

Bennie, J., Davies, T.W., Cruse, D., Bell, F. \& Gaston, K.J. (2017) Artificial light at night alters grassland vegetation species composition and phenology. Journal of Applied Ecology, 55, 442- 
Bennie, J., Davies, T.W., Cruse, D. \& Gaston, K.J. (2016) Ecological effects of artificial light at night on wild plants. Journal of Ecology, 104, 611-620.

Bennie, J., Davies, T.W., Cruse, D., Inger, R. \& Gaston, K.J. (2015a) Cascading effects of artificial light at night: resource-mediated control of herbivores in a grassland ecosystem. Philosophical transactions of the Royal Society of London. Series B, Biological sciences, 370, 20140131-.

Bennie, J., Duffy, J.P., Davies, T.W., Correa-Cano, M.E. \& Gaston, K.J. (2015b) Global trends in exposure to light pollution in natural terrestrial ecosystems. Remote Sensing, 7, 2715-2730.

Bennie, J., Duffy, J.P., Inger, R. \& Gaston, K.J. (2014) Biogeography of time partitioning in mammals. Proceedings of the National Academy of Sciences of the United States of America, 111, 13727-32.

Blanckenhorn, W.U. \& Fairbairn, D.J. (1995) Life history adaptation along a latitudinal cline in the water strider Aquarius remigis (Heteroptera: Gerridae). Journal of Evolutionary Biology, 8, 2141.

Borniger, J.C., Maurya, S.K., Periasamy, M. \& Nelson, R.J. (2014) Acute dim light at night increases body mass, alters metabolism, and shifts core body temperature circadian rhythms. Chronobiology international, 31, 917-25.

Borniger, J.C. \& Nelson, R.J. (2017) Photoperiodic regulation of behavior: Peromyscus as a model system. Seminars in Cell and Developmental Biology, 61, 82-91.

Boulos, Z. \& Macchi, M.M. (2005) Season- and latitude-dependent effects of simulated twilights on circadian entrainment. Journal of Biological Rhythms, 20, 132-144.

Bradshaw, W.E. \& Lounibos, L.P. (1977) Evolution of Dormancy and its Photoperiodic Control in Pitcher-Plant Mosquitoes. Evolution, 31, 546-567.

Brelsford, C.C., Nybakken, L., Kotilainen, T.K. \& Robson, T.. (2019) The influence of spectral 
composition on spring and autumn phenology in trees. Tree physiology, 39, 925-950.

Bronson, F.H. (1988) Mammalian reproductive strategies: genes, photoperiod and latitude. Reproduction, Nutrition, Development, 28, 335-347.

Bulla, M., Valcu, M., Dokter, A.M., Dondua, A.G., Kosztolányi, A., Rutten, A.L., Helm, B., Sandercock, B.K., Casler, B., Ens, B.J., Spiegel, C.S., Hassell, C.J., Küpper, C., Minton, C., Burgas, D., Lank, D.B., Payer, D.C., Loktionov, E.Y., Nol, E., Kwon, E., Smith, F., Gates, H.R., Vitnerová, H., Prüter, H., Johnson, J.A., St Clair, J.J.H., Lamarre, J.F., Rausch, J., Reneerkens, J., Conklin, J.R., Burger, J., Liebezeit, J., Bêty, J., Coleman, J.T., Figuerola, J., Hooijmeijer, J.C.E.W., Alves, J.A., Smith, J.A.M., Weidinger, K., Koivula, K., Gosbell, K., Exo, K.M., Niles, L., Koloski, L., McKinnon, L., Praus, L., Klaassen, M., Giroux, M.A., Sládecek, M., Boldenow, M.L., Goldstein, M.I., Šálek, M., Senner, N., Rönkä, N., Lecomte, N., Gilg, O., Vincze, O., Johnson, O.W., Smith, P.A., Woodard, P.F., Tomkovich, P.S., Battley, P.F., Bentzen, R., Lanctot, R.B., Porter, R., Saalfeld, S.T., Freeman, S., Brown, S.C., Yezerinac, S., Székely, T., Montalvo, T., Piersma, T., Loverti, V., Pakanen, V.M., Tijsen, W. \& Kempenaers, B. (2016) Unexpected diversity in socially synchronized rhythms of shorebirds. Nature, 540, 109-113.

Cahill, G.M. \& Beshare, J.C. (1995) Circadian rhythmicity in vertebrate retinas- Cahill and Besharse 1995.pdf. Progress in Retinal and Eye Research, 14, 267-291.

Cajochen, C., Frey, S., Anders, D., Späti, J., Bues, M., Pross, A., Mager, R., Wirz-Justice, A. \& Stefani, O. (2011) Evening exposure to a light-emitting diodes (LED)-backlit computer screen affects circadian physiology and cognitive performance. Journal of applied physiology (Bethesda, Md. : 1985), 110, 1432-1438.

Caro, T., Dobson, A., Marshall, A.J. \& Peres, C.A. (2014) Compromise solutions between conservation and road building in the tropics. Current Biology, 24, R722-R725.

Carrillo-Vico, A., Guerrero, J.M., Lardone, P.J. \& Reiter, R.J. (2005) A review of the multiple actions of melatonin on the immune system. Endocrine, 27, 189-200. 
Chellappa, S.L., Morris, C.J. \& Scheer, F.A.J.L. (2018) Daily circadian misalignment impairs human cognitive performance task-dependently. Scientific Reports, 8, 3041.

Chen, C., Buhl, E., Xu, M., Croset, V., Rees, J.S., Lilley, K.S., Benton, R., Hodge, J.J.L. \& Stanewsky, R. (2015) Drosophila Ionotropic Receptor 25a mediates circadian clock resetting by temperature. Nature, 527, 516-520.

Cinzano, P., Falchi, F. \& Elvidge, C.D. (2001) The first World Atlas of the artificial night sky brightness. Monthly Notices of the Royal Astronomical Society, 328, 689-707.

Coppack, T. \& Pulido, F. (2004) Photoperiodic response and the adaptability of avian life cycles to environmental change. Advances in Ecological Research, 35, 131-150.

Corlett, R.T. (2012) Climate change in the tropics: The end of the world as we know it? Biological Conservation, 151, 22-25.

Cravens, Z.M., Brown, V.A., Divoll, T.J. \& Boyles, J.G. (2017) Illuminating prey selection in an insectivorous bat community exposed to artificial light at night. Journal of Applied Ecology, 55, $705-713$.

Daan, S. \& Aschoff, J. (1975) Circadian rhythms of locomotor activity in captive birds and mammals: Their variations with season and latitude. Oecologia, 18, 269-316.

Dacke, M., Nilsson, D.-E., Scholtz, C.H., Byrne, M. \& Warrant, E.J. (2003) Insection orientation to polarized moonlight. Nature, $\mathbf{4 2 4}, 33$.

Danilevskii, A.S. (1965) Photoperiodism and seasonal development of insects, Oliver \& Boyd, Edinburgh, UK.

Davies, T.W., Bennie, J., Inger, R. \& Gaston, K.J. (2013a) Artificial light alters natural regimes of night-time sky brightness. Scientific Reports, 3, 1722.

Davies, T.W., Bennie, J., Inger, R., de Ibarra, N.H. \& Gaston, K.J. (2013b) Artificial light pollution: are shifting spectral signatures changing the balance of species interactions? Global Change 
Davies, T.W., Duffy, J.P., Bennie, J. \& Gaston, K.J. (2016) Stemming the tide of light pollution encroaching into marine protected areas. Conservation Letters, 9, 164-171.

Davies, T.W. \& Smyth, T. (2018) Why artificial light at night should be a focus for global change research in the 21st century. Global Change Biology, 24, 872-882.

Dawson, A. (2007) Seasonality in a temperate zone bird can be entrained by near equatorial photoperiods. Proceeding of the Royal society of London B, 274, 721-725.

Dawson, A., King, V.M., Bentley, G.E. \& Ball, G.F. (2001) Photoperiodic control of seasonality in birds. Journal of Biological Rhythms, 16, 365-380.

Desouhant, E., Gomes, E., Mondy, N. \& Amat, I. (2019) Mechanistic, ecological, and evolutionary consequences of artificial light at night for insects: review and prospective. Entomologia Experimentalis et Applicata, 167, 37-58.

Deutsch, C.A., Tewksbury, J.J., Huey, R.B., Sheldon, K.S., Ghalambor, C.K., Haak, D.C. \& Martin, P.R. (2008) Impacts of climate warming on terrestrial ectotherms across latitude. Proceedings of the National Academy of Sciences of the United States of America, 105, 6668-72.

DeWitt, T.J., Sih, A. \& Wilson, D.S. (1998) Cost and limits of phenotypic plasticity. Trends in Ecology \& Evolution, 13, 77-81.

Dominoni, D.M., Carmona-Wagner, E.O., Hofmann, M., Kranstauber, B. \& Partecke, J. (2014) Individual-based measurements of light intensity provide new insights into the effects of artificial light at night on daily rhythms of urban-dwelling songbirds. Journal of Animal Ecology, 83, 681692.

Dorado-Correa, A.M., Rodríguez-Rocha, M. \& Brumm, H. (2016) Anthropogenic noise, but not artificial light levels predicts song behaviour in an equatorial bird. Royal Society Open Science, 3, 160231 . 
Dwyer, R.G., Bearhop, S., Campbell, H.A. \& Bryant, D.M. (2013) Shedding light on light: Benefits of anthropogenic illumination to a nocturnally foraging shorebird. Journal of Animal Ecology, 82, $478-485$.

Endler, J.A. (1990) On the measurement and classification of color in studies of animal color patterns. Biological Journal of the Linnean Society, 41, 315-352.

Erkhert, H.G. (1976) Light-induced activity optimum in night monkeys (Aotus trivirgatus). Folia Primatologica, 25, 186-192.

Falchi, F., Cinzano, P., Duriscoe, D., Kyba, C.C.M., Elvidge, C.D., Baugh, K., Portnov, B.A., Rybnikova, N.A. \& Furgoni, R. (2016) The new world atlas of artificial night sky brightness. Science Advances, 2, e1600377-e1600377.

ffrench-Constant, R.H., Somers-Yeates, R., Bennie, J., Economou, T., Hodgson, D., Spalding, A. \& McGregor, P.K. (2016) Light pollution is associated with earlier tree budburst across the United Kingdom. Proceedings of the Royal Society B: Biological Sciences, 283, 20160813.

Firebaugh, A. \& Haynes, K.J. (2016) Experimental tests of light-pollution impacts on nocturnal insect courtship and dispersal. Oecologia, 182, 1203-1211.

Fonken, L.K., Workman, J.L., Walton, J.C., Weil, Z.M., Morris, J.S., Haim, A. \& Nelson, R.J. (2010) Light at night increases body mass by shifting the time of food intake. Proceedings of the National Academy of Sciences, 107, 18664-18669.

Frank, T.M., Gabbert, W.C., Chaves-Campos, J. \& LaVal, R.K. (2019) Impact of artificial lights on foraging of insectivorous bats in a Costa Rican cloud forest. Journal of Tropical Ecology, 35, 817.

De Freitas, J.R., Bennie, J., Mantovani, W. \& Gaston, K.J. (2017) Exposure of tropical ecosystems to artificial light at night: Brazil as a case study. PLoS ONE, 12, 1-12.

Gaston, K.J., Bennie, J., Davies, T.W. \& Hopkins, J. (2013) The ecological impacts of nighttime light 
Gaston, K.J., Davies, T.W., Nedelec, S.L. \& Holt, L.A. (2017) Impacts of artificial light at night on biological timings. Annual Review of Ecology, Evolution, and Systematics, 48, 49-68.

Gaston, K.J., Visser, M.E. \& Hölker, F. (2015) The biological impacts of artificial light at night: the research challenge. Philosophical transactions of the Royal Society of London. Series B, Biological sciences, 370, 20140133-.

van Geffen, K.G., van Eck, E., de Boer, R.A., van Grunsven, R.H.A., Salis, L., Berendse, F. \& Veenendaal, E.M. (2015) Artificial light at night inhibits mating in a Geometrid moth. Insect Conservation and Diversity, 8, 282-287.

Van Geffen, K.G., Van Grunsven, R.H.A., Van Ruijven, J., Berendse, F. \& Veenendaal, E.M. (2014) Artificial light at night causes diapause inhibition and sex-specific life history changes in a moth. Ecology and Evolution, 4, 2082-2089.

Gineste, B., Souquet, M., Couzi, F.X., Giloux, Y., Philippe, J.S., Hoarau, C., Tourmetz, J., Potin, G. \& Le Corre, M. (2017) Tropical Shearwater population stability at Reunion Island, despite light pollution. Journal of Ornithology, 158, 385-394.

Gomez, D., Richardson, C., Lengagne, T., Plénet, S., Joly, P., Léna, J.-P. \& Théry, M. (2009) The role of nocturnal vision in mate choice: female prefer conspicuous males in the European treefrog (Hyla arborea). Proceedings of Royal Society London B, 276, 2351-2358.

González-Bernal, E., Greenlees, M.J., Brown, G.P. \& Shine, R. (2016) Toads in the backyard: why do invasive cane toads (Rhinella marina) prefer buildings to bushland? Population Ecology, 58, 293-302.

Grant, R.A., Chadwick, E.A. \& Halliday, T. (2009) The lunar cycle: a cue for amphibian reproductive phenology? Animal Behaviour, 78, 349-357.

Grubisic, M., van Grunsven, R.H.A., Kyba, C.C.M., Manfrin, A. \& Hölker, F. (2018) Insect declines 

and agroecosystems: does light pollution matter? Annals of Applied Biology, 173, 180-189.

681

682

683

684

685

686

687

688

689

690

691

692

693

694

695

696

697

698

699

Guenard, B., Weiser, M.D. \& Dunn, R.R. (2012) Global models of ant diversity suggest regions where new discoveries are most likely are under disproportionate deforestation threat. Proceedings of the National Academy of Sciences, 109, 7368-7373.

Guetté, A., Godet, L., Juigner, M. \& Robin, M. (2018) Worldwide increase in artificial light at night around protected areas and within biodiversity hotspots. Biological Conservation, 223, 97-103.

Gupta, P.D. \& Pushkala, K. (2016) Increased Incidence of Breast Cancer Due to Long Exposure of Light. Journal of Analytical Oncology, 5, 146-152.

Gwinner, E. (1996) Circannual clocks in avian reproduction and migration. Ibis, 138, 47-63.

Hailman, J.P. \& Jaeger, R.G. (1974) Phototactic responses to spectrally dominant stimuli and use of colour vision by adult anuran amphibians: A comparative survey. Animal Behaviour, 22, 757795.

Hansen, J., Sato, M., Ruedy, R., Lo, K., Lea, D.W. \& Medina-Elizade, M. (2006) Global temperature change James. Proc Natl Acad Sci USA, 103, 14288-14293.

Hardeland, R., Cardinali, D.P., Srinivasan, V., Spence, D.W., Brown, G.M. \& Pandi-Perumal, S.R. (2011) Melatonin-A pleiotropic, orchestrating regulator molecule. Progress in Neurobiology, 93, 350-384.

Hau, M., Wikelski, M. \& Wingfield, J.C. (1998) A neotropical forest bird can measure the slight changes in tropical photoperiod. Proceedings of the Royal Society B: Biological Sciences, $\mathbf{2 6 5}$, 89-95.

Helm, B., Visser, M.E., Schwartz, W., Kronfeld-Schor, N., Gerkema, M., Piersma, T. \& Bloch, G. (2017) Two sides of a coin: ecological and chronobiological perspectives of timing in the wild. Philosophical Transactions of the Royal Society B: Biological Sciences, 372, 20160246. 

Human Variation: From the Laboratory to the Field (ed. by S.U. C.G. Nicholas Mascie-Taylor, Akira Yasukouchi), pp. 69-83. CRC Press, Boca Raton.

Hillebrand, H. (2004) On the generality of the latitudinal diversity gradient. 2The American Naturalist, 163, 192-211.

Hölker, F., Wolter, C., Perkin, E.K. \& Tockner, K. (2010) Light pollution as a biodiversity threat. Trends in Ecology and Evolution, 25, 681-682.

Hölker, F., Wurzbacher, C., Weissenborn, C., Monaghan, M.T., Holzhauer, S.I.J. \& Premke, K. (2015) Microbial diversity and community respiration in freshwater sediments influenced by artificial light at night. Philosophical Transactions of the Royal Society B-Biological Sciences, 370, 20140130.

Honnen, A.C., Johnston, P.R. \& Monaghan, M.T. (2016) Sex-specific gene expression in the mosquito Culex pipiens f. molestus in response to artificial light at night. BMC Genomics, 17, 1-10.

Hopkins, G.R., Gaston, K.J., Visser, M.E., Elgar, M.A. \& Jones, T.M. (2018) Artificial light at night as a driver of evolution across urban-rural landscapes. Frontiers in Ecology and the Environment, 8, 472-479.

Hut, R.A. \& Beersma, D.G.M. (2011) Evolution of time-keeping mechanisms: early emergence and adaptation to photoperiod. Philosophical Transactions of the Royal Society B: Biological Sciences, 366, 2141-2154.

Hut, R.A., Paolucci, S., Dor, R., Kyriacou, C.P. \& Daan, S. (2013) Latitudinal clines: an evolutionary view on biological rhythms. Proceedings of the Royal Society B: Biological Sciences, 280, 20130433-20130433.

Ibisch, P.L., Hoffmann, M.T., Kreft, S. \& Kati, V.I. (2016) A global map of roadless areas and their conservation status. Science, 354, 1423-1427.

IPCC (2014) Climate Change 2014: Synthesis Report. Contribution of Working Groups I, II and III to 
the Fifth Assessment Report of the Intergovernmental Panel on Climate Change, Core Writi. (ed. by R.K. Pachauri) and L.A. Meyer) IPCC, Geneva, Switzerland.

Jenkins, C.N., Guénard, B., Diamond, S.E., Weiser, M.D. \& Dunn, R.R. (2013) Conservation implications of divergent global patterns of ant and vertebrate diversity. Diversity and Distributions, 19, 1084-1092.

Johnsen, S. (2011) Measuring Light. The Optics of Life: A Biologist's Guide to Light in Nature, 237270.

Kelber, A., Balkenius, A. \& Warrant, E.J. (2002) Scotopic colour vision in nocturnal hawkmoths. Nature, 419, 922-925.

Kelber, A. \& Roth, L.S. V (2006) Nocturnal colour vision-not as rare as we might think. The Journal of experimental biology, 209, 781-8.

Kelber, A., Yovanovich, C. \& Olsson, P. (2017) Thresholds and noise limitations of colour vision in dim light. Philosophical Transactions of the Royal Society B: Biological Sciences, 372, 20160065.

King, M.D., Platnick, S., Menzel, W.P., Ackerman, S.A. \& Hubanks, P.A. (2013) Spatial and temporal distribution of clouds observed by MODIS onboard the terra and aqua satellites. IEEE Transactions on Geoscience and Remote Sensing, 51, 3826-3852.

Kitoh, A., Endo, H., Krishna Kumar, K., Cavalcanti, I.F.A., Goswami, P. \& Zhou, T. (2013) Monsoons in a changing world: A regional perspective in a global context. Journal of Geophysical Research: Atmospheres, 118, 3053-3065.

Knop, E., Zoller, L., Ryser, R., Gerpe, C., Hörler, M. \& Fontaine, C. (2017) Artificial light at night as a new threat to pollination. Nature, 548, 206-209.

Kocifaj, M. \& Lamphar, H.A.S. (2014) Quantitative analysis of night skyglow amplification under cloudy conditions. Monthly Notices of the Royal Astronomical Society, 443, 3665-3674. 
Kreft, H. \& Jetz, W. (2007) Global patterns and determinants of vascular plant diversity. Proceedings of the National Academy of Sciences, 104, 5925-5930.

Kronfeld-Schor, N., Dominoni, D., de la Iglesia, H., Levy, O., Herzog, E.D., Dayan, T. \& HelfrichForster, C. (2013) Chronobiology by moonlight. Proceedings of the Royal Society B: Biological Sciences, 280, 20123088-20123088.

Kronfeld-Schor, N., Visser, M.E., Salis, L. \& van Gils, J.A. (2017) Chronobiology of interspecific interactions in a changing world. Philosophical Transactions of the Royal Society B: Biological Sciences, 372, 20160248.

Kurvers, R.H.J.M. \& Hölker, F. (2015) Bright nights and social interactions: A neglected issue. Behavioral Ecology, 26, 334-339.

Kyba, C.C.M., Kuester, T., Sánchez de Miguel, A., Baugh, K., Jechow, A., Hölker, F., Bennie, J., Elvidge, C.D., Gaston, K.J. \& Guanter, L. (2017a) Artificially lit surface of Earth at night increasing in radiance and extent. Science Advances, 3, e1701528.

Kyba, C.C.M., Mohar, A. \& Posch, T. (2017b) How bright is moonlight? A\&G Astronomy and Geophysics, 58, 31-32.

Kyba, C.C.M., Ruhtz, T., Fischer, J. \& Hölker, F. (2011) Cloud coverage acts as an amplifier for ecological light pollution in urban ecosystems. PLoS ONE, 6, e17307.

van Langevelde, F., Grunsven, R.H.A. Van, Veenendaal, E.M. \& Fijen, T.P.M. (2017) Artificial night lighting inhibits feeding in moths. Biology letters, 13, 20160874.

Laporte, N.T., Stabach, J.A., Grosch, R., Lin, T.S. \& Goetz, S.J. (2007) Expansion of Industrial Logging in Central Africa. Science, 316, 1451.

Laurance, W.F., Goosem, M. \& Laurance, S.G.W. (2009) Impacts of roads and linear clearings on tropical forests. Trends in Ecology and Evolution, 24, 659-669. 

E2157-E2158.

Lesku, J.A., Rattenborg, N.C., Valcu, M., Vyssotski, A.L., Kuhn, S., Kuemmeth, F., Heidrich, W. \& Kempenaers, B. (2012) Adaptive sleep loss in polygynous pectoral sandpipers. Science, 337, $1654-1658$.

Lewanzik, D. \& Voigt, C.C. (2014) Artificial light puts ecosystem services of frugivorous bats at risk. Journal of Applied Ecology, 51, 388-394.

Lewis, R.A., Farner, D.S. \& King, J.R. (1974) Photoperiodic Responses of a Subtropical Population of the Finch (Zonotrichia capensis hypoleuca ). The condor, 76, 233-237.

Longcore, T. \& Rich, C. (2004) Ecological light pollution. Frontiers in Ecology and the Environment, 2, 191-198.

Luginbuhl, C.B., Boley, P.A. \& Davis, D.R. (2014) The impact of light source spectral power distribution on sky glow. Journal of Quantitative Spectroscopy and Radiative Transfer, 139, 2126.

MacGregor, C.J., Evans, D.E., Fox, R. \& Pocock, M.J.O. (2017) The dark side of street lighting: impacts on moths and evidence for the disruption of nocturnal pollen transport. Global Change Biology, 23, 697-707.

Macgregor, C.J., Pocock, M.J.O., Fox, R. \& Evans, D.M. (2019) Effects of street lighting technologies on the success and quality of pollination in a nocturnally pollinated plant. Ecosphere, $\mathbf{1 0}$.

Martín-Olalla, J.M. (2019) Seasonal synchronization of sleep timing in industrial and pre-industrial societies. Scientific Reports, 9, 1-13.

Mathews, F., Roche, N., Aughney, T., Jones, N., Day, J., Baker, J. \& Langton, S. (2015) Barriers and benefits: implications of artificial night-lighting for the distribution of common bats in Britain and Ireland. Philosophical transactions of the Royal Society of London. Series B, Biological 
801

802

803

804

805

806

807

808

809

810

Mauritsen, T. \& Stevens, B. (2015) Missing iris effect as a possible cause of muted hydrological change and high climate sensitivity in models. Nature Geoscience, $\mathbf{8}, 346-351$.

Mayer, I., Bornestaf, C. \& Borg, B. (1997) Melatonin in non-mammalian vertebrates: Physiological role in reproduction? Comparative Biochemistry and Physiology - A Physiology, 118, 515-531.

Merckx, T. \& Van Dyck, H. (2019) Urbanization-driven homogenization is more pronounced and happens at wider spatial scales in nocturnal and mobile flying insects. Global Ecology and Biogeography, DOI: 10.1111/geb.12969.

Meyer, L.A. \& Sullivan, S.M.P. (2013) Bright lights, big city: Influences of ecological light pollution on reciprocal stream-riparian invertebrate fluxes. Ecological Applications, 23, 1322-1330.

Millenium Ecosystem Assessment (2005) Ecosystems and human well-being: biodiversity synthesis, World Resources Institute, Washington, DC.

Miller, C.R., Barton, B.T., Zhu, L., Radeloff, V.C., Oliver, K.M., Harmon, J.P. \& Ives, A.R. (2017) Combined effects of night warming and light pollution on predator - Prey interactions. Proceedings of the Royal Society B: Biological Sciences, 284, 20171195.

Mills, A.M. (2008) Latitudinal gradients of biologically useful semi-darkness. Ecography, 31, 578582.

Mittelbach, G.G., Schemske, D.W., Cornell, H. V., Allen, A.P., Brown, J.M., Bush, M.B., Harrison, S.P., Hurlbert, A.H., Knowlton, N., Lessios, H.A., McCain, C.M., McCune, A.R., McDade, L.A., McPeek, M.A., Near, T.J., Price, T.D., Ricklefs, R.E., Roy, K., Sax, D.F., Schluter, D., Sobel, J.M. \& Turelli, M. (2007) Evolution and the latitudinal diversity gradient: Speciation, extinction and biogeography. Ecology Letters, 10, 315-331.

Moore, M., Pierce, S., Walsh, H., Kvalvik, S. \& Lim, J. (2000) Urban light pollution alters the diel vertical migration of Daphnia. Internationale Vereinigung fur Theoretische und Angewandte 
Nadis, S. (2002) Biologists join drive to turn down the lights. Nature, 419, 868.

826

827

Navara, K.J. \& Nelson, R.J. (2007) The dark side of light at night: Physiological, epidemiological, and ecological consequences. Journal of Pineal Research, 43, 215-224.

Norris, J.R., Allen, R.J., Evan, A.T., Zelinka, M.D., O’Dell, C.W. \& Klein, S.A. (2016) Evidence for climate change in the satellite cloud record. Nature, 536, 72-75.

Van Oort, B.E.H., Tyler, N.J.C., Gerkema, M.P., Folkow, L., Blix, A.S. \& Stokkan, K.A. (2005) Circadian organization in reindeer. Nature, 438, 1095-1096.

Owens, A.C.S. \& Lewis, S.M. (2018) The impact of artificial light at night on nocturnal insects: A review and synthesis. Ecology and Evolution, 8, 11337-11358.

Paolucci, S., Van de Zande, L. \& Beukeboom, L.W. (2013) Adaptive latitudinal cline of photoperiodic diapause induction in the parasitoid Nasonia vitripennis in Europe. Journal of Evolutionary Biology, 26, 705-718.

Pawson, S.M. \& Bader, M.K.-F. (2014) LED lighting increases the ecological impact of light pollution irrespective of color temperature. Ecological applications, 24, 1561-1568.

Peres, R., Reitzel, A.M., Passamaneck, Y., Afeche, S.C., Cipolla-Neto, J., Marques, A.C. \& Martindale, M.Q. (2014) Developmental and light-entrained expression of melatonin and its relationship to the circadian clock in the sea anemone Nematostella vectensis. EvoDevo, 5, 1-18.

Perkin, E.K., Hölker, F., Richardson, J.S., Sadler, J.P., Wolter, C. \& Tockner, K. (2011) The influence of artificial light on stream and riparian ecosystems: questions, challenges, and perspectives. Ecosphere, 2, art122.

Perry, G., Buchanan, B.W., Fisher, R.N., Salmon, M. \& Wise, S.E. (2008) Effects of artificial night lighting on amphibians and reptiles in urban environments. Urban Herpetology (ed. by J.C. Mitchell), R.E. Jung Brown), and B. Bartholomew), pp. 239-256. Urban Herpetology. Society 
Prugh, L.R. \& Golden, C.D. (2014) Does moonlight increase predation risk? Meta-analysis reveals divergent responses of nocturnal mammals to lunar cycles. Journal of Animal Ecology, 83, 504514.

Rich, C. \& Longcore, T. (2006a) Ecological consequences of artificial night lighting, (ed. by C. Rich) and T. Longcore) Island Press, Washington D.C.

Rich, C. \& Longcore, T. (2006b) Ecological consequences of artificial night lighting, (ed. by C. Rich) and T. Longcore) Island Press, Washington.

Rivas, G.B.S., Teles-de-Freitas, R., Pavan, M.G., Lima, J.B.P., Peixoto, A.A. \& Vieira Bruno, R. (2018) Effects of light and temperature on daily activity and clock gene expression in two mosquito disease vectors. Journal of Biological Rhythms, 33, 272-288.

Rowan, W. (1925) Relation of light to bird migration and developmental changes. Nature, 115, 494495.

Salmon, M. (2003) Artificial lighting and sea turtles. The Biologist, 50, 163-168.

Sanders, D. \& Gaston, K.J. (2018) How ecological communities respond to artificial light at night. Journal of Experimental Zoology Part A: Ecological and Integrative Physiology, 329, 394-400.

Sanders, D., Kehoe, R., Tiley, K., Bennie, J., Cruse, D., Davies, T.W., Frank van Veen, F.J. \& Gaston, K.J. (2015) Artificial nighttime light changes aphid-parasitoid population dynamics. Scientific reports, $\mathbf{5}, 15232$.

Schmidt, B.R., Feldmann, R. \& Schaub, M. (2005) Demographic processes underlying population growth and decline in Salamandra salamandra. Conservation Biology, 19, 1149-1156.

Seto, K.C., Güneralp, B. \& Hutyra, L.R. (2012) Global forecasts of urban expansion to 2030 and direct impacts on biodiversity and carbon pools. Proceedings of the National Academy of Sciences of the United States of America, 109, 16083-16088. 
Shimmura, T., Nakayama, T., Shinomiya, A. \& Yoshimura, T. (2017) Seasonal changes in color perception. General and Comparative Endocrinology, 260, 171-174.

Sih, A., Bell, A.M. \& Kerby, J.L. (2004) Two stressors are far deadlier than one. Trends in Ecology \& Evolution, 19, 274-276.

Da Silva, A. \& Kempenaers, B. (2017) Singing from North to South: Latitudinal variation in timing of dawn singing under natural and artificial light conditions. Journal of Animal Ecology, 86, 12861297.

Da Silva, A., Valcu, M. \& Kempenaers, B. (2015) Light pollution alters the phenology of dawn and dusk singing in common European songbirds. Philosophical Transactions of the Royal Society of London B: Biological Sciences, 370, 1-9.

Silverin, B., Massa, R. \& Stokkan, K.A. (1993) Photoperiodic adaptation to breeding at different latitudes in great tits. General and Comparative Endocrinology, 90, 14-22.

Singhal, R.K., Kumar, M. \& Bose, B. (2019) Eco-physiological Responses of Artificial Night Light Pollution in Plants. Russian Journal of Plant Physiology, 66, 190-202.

Smith, M. (2009) Time to turn off the lights. Nature, 457, 27.

Solano-Lamphar, H.A. \& Kocifaj, M. (2018) Numerical research on the effects the skyglow could have in phytochromes and RQE photoreceptors of plants. Journal of Environmental Management, 209, 484-494.

Somanathan, H., Borges, R.M., Warrant, E.J. \& Kelber, A. (2008) Nocturnal bees learn landmark colours in starlight. Current Biology, 18, 996-997.

Stevens, R.G., Brainard, G.C., Blask, D.E., Lockley, S.W. \& Motta, M.E. (2013) Adverse health effects of nighttime lighting: Comments on american medical association policy statement. American Journal of Preventive Medicine, 45, 343-346. 

rhythmicity: is that a problem? Philosophical transactions of the Royal Society of London. Series B, Biological sciences, 370, 20140120.

Stone, E.L., Jones, G. \& Harris, S. (2009) Street lighting disturbs commuting bats. Current biology: $C B, 19,1123-1127$.

Le Tallec, T., Perret, M. \& Théry, M. (2013) Light pollution modifies the expression of daily rhythms and behavior patterns in a nocturnal primate. PLOS ONE, 8, e79250.

Tallec, T. Le, Théry, M. \& Perret, M. (2016) Melatonin concentrations and timing of seasonal reproduction in male mouse lemurs ( Microcebus murinus ) exposed to light pollution. Journal of Mammalogy, 97, 753-760.

Tan, D.X., Hardeland, R., Manchester, L.C., Paredes, S.D., Korkmaz, A., Sainz, R.M., Mayo, J.C., Fuentes-Broto, L. \& Reiter, R.J. (2010) The changing biological roles of melatonin during evolution: From an antioxidant to signals of darkness, sexual selection and fitness. Biological Reviews, 85, 607-623.

Terman, M. \& Terman, J. (1985) A circadian pacemaker for visual sensitivity? Ann N Y Acad Sci., 453, 147-61.

Thakurdas, P., Sharma, S., Vanlalhriatpuia, K., Sinam, B., Chib, M., Shivagaje, A. \& Joshi, D. (2009) Light at night alters the parameters of the eclosion rhythm in a tropical fruit fly, Drosophila jambulina. Chronobiology International, 26, 1575-86.

Thums, M., Whiting, S.D., Reisser, J., Pendoley, K.L., Pattiaratchi, C.B., Proietti, M., Hetzel, Y., Fisher, R. \& Meekan, M.G. (2016) Artificial light on water attracts turtle hatchlings during their near shore transit. Royal Society Open Science, 3, 160142.

Touzot, M., Teulier, L., Lengagne, T., Secondi, J., Théry, M., Libourel, P.A., Guillard, L. \& Mondy, N. (2019) Artificial light at night disturbs activity and energy allocation of common toad during the breeding period. Conservation Physiology, 7, coz002. 
920

921

922

923

924

925

926

927

928

929

930

931

932

933

934

935

936

937

938

939

940

Underwood, H. (1989) The pineal and melatonin: Regulators of circadian function in lower vertebrates. Experientia, 45, 914-922.

United Nations Department of Economic and social affair Population division (2017) World population 2017,.

Vignoli, L. \& Luiselli, L. (2013) Better in the dark: Two Mediterranean amphibians synchronize reproduction with moonlit nights. Web Ecology, 13, 1-11.

van der Vinne, V., Riede, S.J., Gorter, J.A., Eijer, W.G., Sellix, M.T., Menaker, M., Daan, S., Pilorz, V. \& Hut, R.A. (2014) Cold and hunger induce diurnality in a nocturnal mammal. Proceedings of the National Academy of Sciences, 111, 15256-15260.

Walker, W.H., Meléndez-Fernández, O.H., Nelson, R.J. \& Reiter, R.J. (2019) Global climate change and invariable photoperiods: A mismatch that jeopardizes animal fitness. Ecology and Evolution, 9, 10044-10054.

Welbourne, L.E., Morland, A.B. \& Wade, A.R. (2015) Human colour perception changes between seasons. Current Biology, 25, R646-R647.

Westra, S., Fowler, H.J., Evans, J.P., Alexander, L. V., Berg, P., Johnson, F., Kendon, E.J., Lenderink, G. \& Roberts, N.M. (2014) Future changes to the intensity and frequency of short-duration extreme rainfall. Reviews of Geophysics, 52, 522-555.

Willig, M.R., Kaufman, D.M. \& Stevens, R.D. (2003) Latitudinal gradients of biodiversity: pattern, process, scale, and synthesis. Annual Review of Ecology, Evolution, and Systematics, 34, 273309.

Wodzicki, K.R. \& Rapp, A.D. (2016) Long-term characterization of the Pacific ITCZ using TRMM, GPCP, and ERA-Interim. Journal of Geophysical Research, 121, 3153-3170.

Yammouni, R., Bozzano, A. \& Douglas, R.H. (2011) A latitudinal cline in the efficacy of endogenous signals: evidence derived from retinal cone contraction in fish. Journal of Experimental Biology, 

214, 501-508.

945 Yovanovich, C.A.M., Koskela, S.M., Nevala, N., Kondrashev, S.L., Kelber, A. \& Donner, K. (2017)

946 The dual rod system of amphibians supports colour discrimination at the absolute visual

947 threshold. Philosophical Transactions of the Royal Society B: Biological Sciences, 372,

$948 \quad 20160066$.

949

950 Data accessibility statement - Data be will made available in Repository upon acceptance of

951 the manuscript 
Figure 1 Mean latitudinal distribution of ALAN and cloud cover fraction (A and C) as measured from

954 955
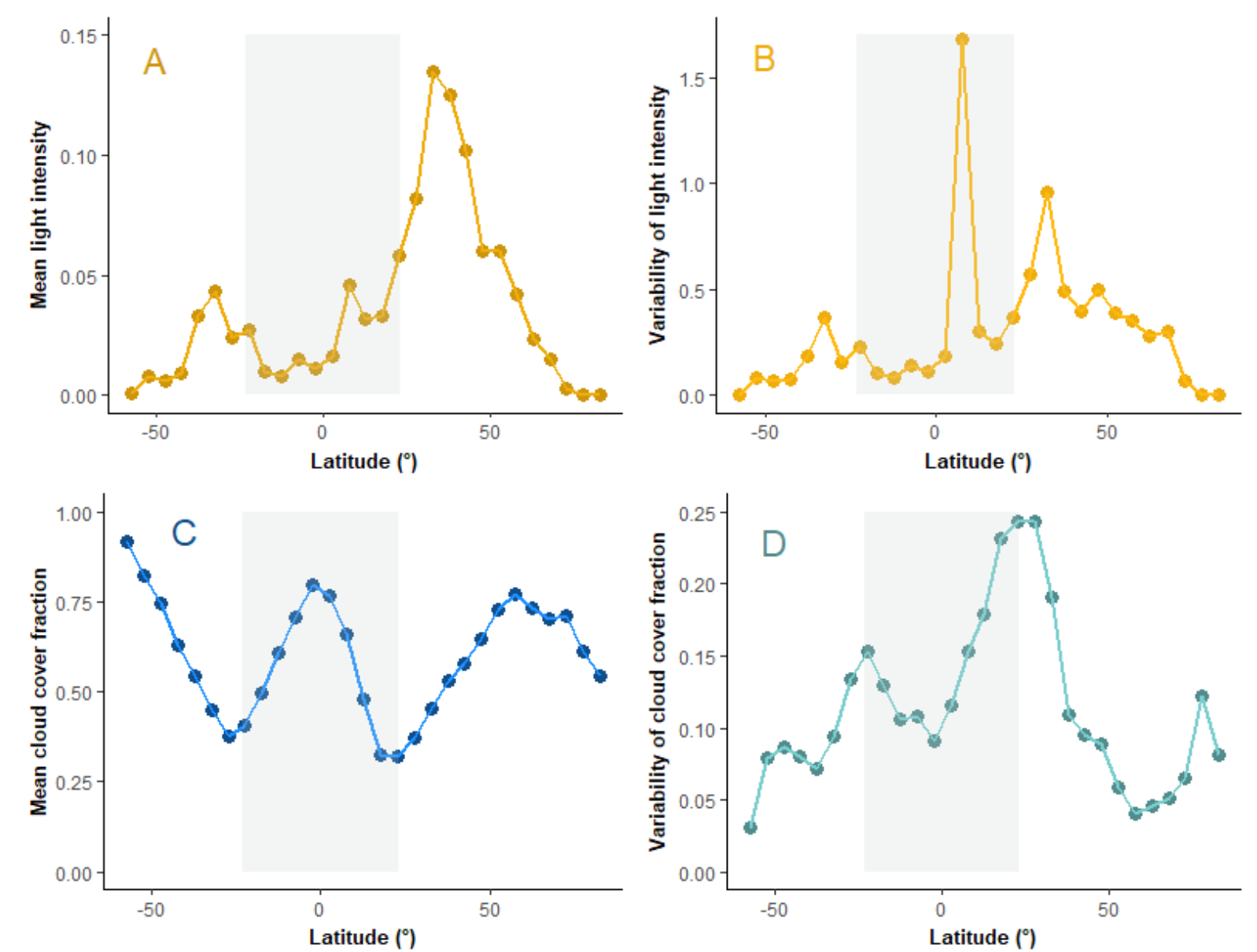

963

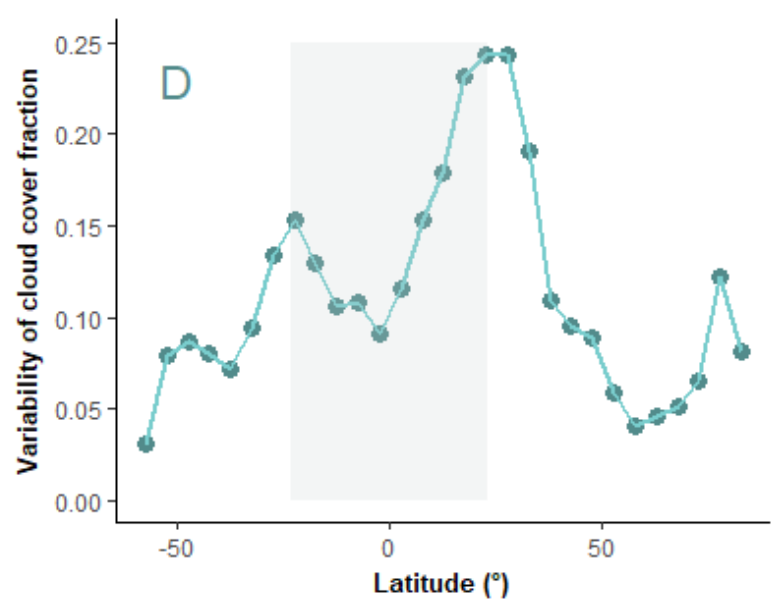


Figure 2 (A-C) Annual variation in twilight for three towns at low, mid, and high latitudes. Twilight 966 represents the periods of the day when sun declination is between $0^{\circ}$ and $18^{\circ}$ below horizon. When the declination is lower, the sun does contribute to ambient light. The right column shows for two lighting scenarios the annual variation in the time period when ALAN elevates the ambient light level outside the twilight periods. Artificial lights are turned off at midnight (D) or stay turned on all night (E). Sources : https://www.esrl.noaa.gov/gmd/grad/solcalc/; https://earthsky.org/?p=235797.

971
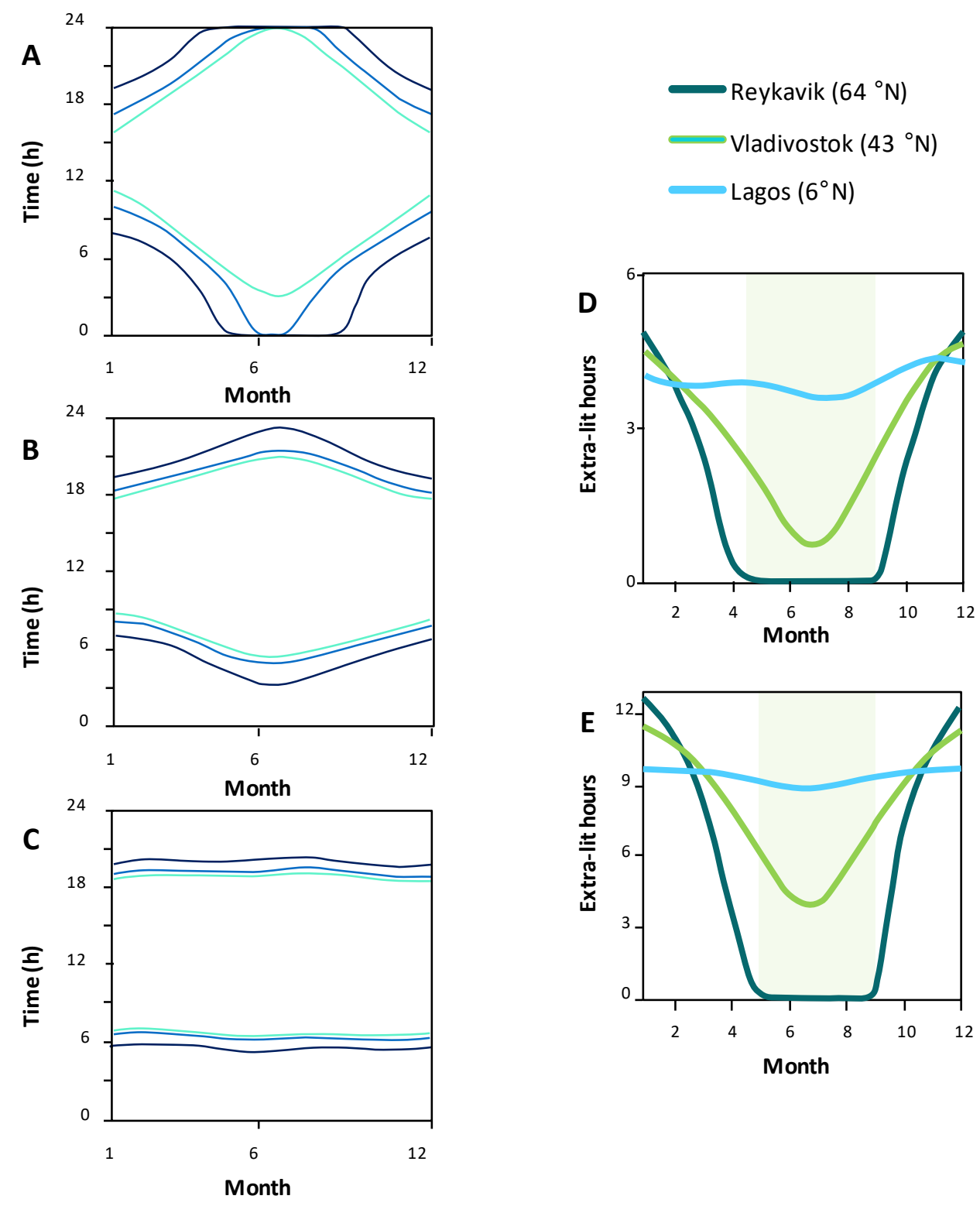

$\operatorname{Lagos}\left(6^{\circ} \mathrm{N}\right)$ 
973 Figure 3 Expected change in Urbanization/demography between 2018 and 2030 (Source UNICEF,

974 United Nations). The green latitudinal band represents the intertropical zone.

975

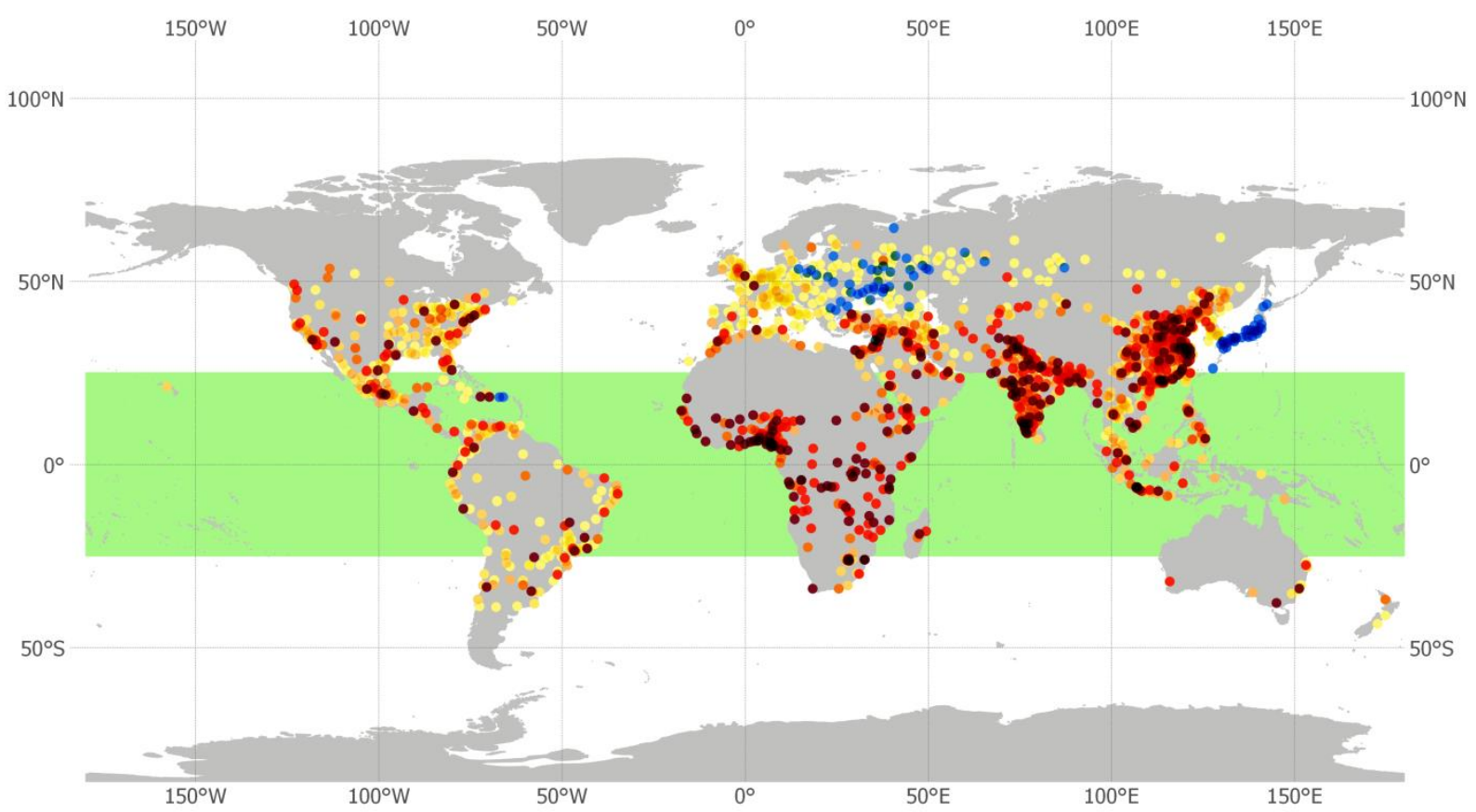

Inhabitant change 2020-2035 (thousands)

$\begin{array}{lll}-1380-0 & 101-165 & \bullet 356-645 \\ 1-80 & -166-235 & \bullet 646-13055 \\ 81-100 & \bullet 236-355 & \end{array}$

976

977 
